\title{
A PUHA (SOFT) ÉS A KEMÉNY (HARD) KÉSZSÉGEK MUNKAERŐPIACI SZÜKSÉGESSÉGE
}

\author{
HORVÁTH-CSIKÓS GABRIELLA ${ }^{\mathrm{a}, *}$ - JUHÁSZ TÍMEA ${ }^{\mathrm{b}}$ \\ ${ }^{a}$ Budapesti Gazdasági Egyetem, Külkereskedelmi Kar, \\ Nemzetközi Üzleti Szaknyelvek Tanszék

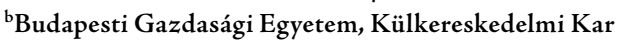 \\ Beérkezett: 2020. december 15., elfogadva: 2021. október 25.
}

Jelen tanulmány célja annak vizsgálata, hogy a jelenlegi munkaerőpiacon a puha (soft) vagy a kemény (hard) készségek jelennek meg erősebb elvárásként a munkavállalók szerint. A kutatás eredménye rámutatott arra, hogy egyes puha készségek (például a rugalmasság, kommunikáció, csapatmunka) erősebb elvárásként vannak jelen a munkaerőpiacon, mint az olyan kemény készégek, mint például a szakmai ismeret. $\mathrm{A} z$ eredmények azt is mutatják, hogy a puha és a kemény készségekkel szembeni elvárások kevésbé függnek össze, vagyis a munkavállalók szerint a munkáltatók nem rendszerszintü, egymással szorosan kapcsolatban álló készségekként értékelik ezeket. Eredményeink arra is rámutatnak, hogy a puha és kemény készségek önbevalláson alapuló szintje erősen összefügg a válaszadó nemével, életkorával és iskolai végzettségével.

Kulcsszavak» soft készségek, hard készségek, munkavállalók, munkaerőpiac

The aim of the present study is to examine whether soft or hard skills are seen as the strongest requirement in the current labour market. The results of the research showed that some soft skills (e.g. flexibility, communication, teamwork) are almost more strongly expected than hard skills (e.g. professional knowledge). These results basically indicate that expectations of soft and hard skills are less interrelated and that employees perceive employers as valuing these skills as non-systemic, closely related skills. Our results also show that self-reported levels of soft and hard skills are strongly correlated with gender, age and educational attainment of the respondent.

Keywords: soft skills, hard skills, employees, labour market

\footnotetext{
* Levelező szerző: Dr. Horváth-Csikós Gabriella, Budapesti Gazdasági Egyetem, Külkereskedemi Kar, Nemzetközi Üzleti Szaknyelvek Tanszék, 1165 Budapest, Farkasfog utca 23/2.

E-mail: drhorvathcsikosgabriella@gmail.com
} 


\section{Elméleti háttér}

$\mathrm{A}$ z Európai Unió képességstratégiájának és képességpolitikájának 2011-ben kidolgozott első, majd 2019-ben megjelent második generációja (European Commission 2011) az oktatáspolitikai gondolkodás új paradigmáját jelenti, amely különbséget tesz a formális végzettségek és a tényleges képességek között. Mivel a munkaerőpiac a kvalifikációval szemben egyre inkább a képességre helyezi a hangsúlyt, felértékelődik a nem formális, a munka világában történő, valamint az informális tanulás.

A képességstratégia szerint a munkavállalói, kínálati oldal a képességek megteremtését és ennek eredményeként az egyének által felhalmozott képességkészleteket jelenti. A képességkészlet forrása azonban nemcsak a formális oktatás és képzés területén megszerzett, bizonyítvánnyal, diplomával igazolt kvalifikáció, hanem a nem formális és informális tanulási területeken szerzett, folyamatosan változó, gazdagodó tudás- és képességterületek is. Az egyén képességkészlete az adott munkaerőpiacon vagy megfelelö, vagy hiányként, illetve többletként jelenik meg. Mindez a gazdaságban képesség-egyensúly vagy egyensúlytalanságként mutatkozik meg (Halász 2013; Tribble 2020).

A skill kifejezés tartalmát tekintve inkább a készség szónak felel meg, annak ellenére, hogy sokszor szinte már automatikusan képességként fordítjuk. A képesség kifejezés olyan tudásfajtára utal, amely valamilyen aktivitást tesz lehetővé a cselekvő számára, ezzel szemben a készség a tudás része, a tanulás eredménye, vagyis amikor megfelelő számú gyakorlás eredményeként a cselekvéssor automatikussá tud válni.

A munkahelyi jó teljesítmény a puha készségek (soft skillek) és a kemény készségek (hard skillek) megfelelő kombinációjából eredeztethető. A kemény készségek könnyebben meghatározható és mérhető készségek, mint a puha készségek. A kemény készségek a munkavállalók képességét mutatják egy adott feladat elvégzésében, a puha készségek pedig inkább arról szólnak, hogyan alkalmazkodnak, mennyire együttmúködőek, hogyan oldják meg a problémákat és hogyan hoznak döntéseket a munkavállalóik adott helyzetekben. A puha készségek fontos szerepet töltenek be az egyén személyiségének kialakításában.

Schulz (2008) tanulmányában arra ösztönzi az oktatókat, hogy fektessenek nagyobb hangsúlyt tanítványaik soft készségeinek fejlesztésére. Seetha (2013) is arra utal tanulmányában, hogy a munkáltatók inkább azokat a személyeket veszik fel és támogatják, akik találékonyak, képesek önállóan jól dolgozni és soft készségekkel is bírnak. Hangsúlyozza továbbá a soft készségek képzési programokba és tantervbe való beépítésének szükségességét, kiemelve a soft készségek fejlesztése során alkalmazandó különböző tanítási módszereket (Seetha 2013). A soft skillek fejlesztése azonban nem könnyü, sok esetben meglehetősen költséges, időt, pénzt és energiát igényel. Laker és Powell (2011) részletesen veszi górcső alá a soft és hard skillek fejlesztése közötti különbségeket, különös tekintettel a tudástranszfer mértékére.

A Harvard Egyetem egyik kutatása szerint a munkahelyi sikerek nyolcvanöt százaléka köszönhető soft skilleknek, míg csupán tizenöt százaléka a hard skilleknek (National Soft Skills Association 2015). A LinkedIn Global Talent Trends 2019 jelentése szerint a szakértők 92 százaléka gondolja azt, hogy a puha készségek ugyanolyan fontosak vagy még fontosabbak is, mint a kemény készségek. A szakértők 89 százaléka azt állította, hogy ha 
egy újonnan felvett munkavállaló mégsem váltja be a hozzá füzött reményeket, akkor az azért van, mert a szükséges és kritikus puha skilleknek nincs, vagy nem megfelelően van birtokában (LinkedIn 2019).

Egy, a gazdasági felsőfokú nem diplomát adó szakképzést fókuszba állító hazai kutatás szerint a vállalkozások a gazdasági végzettségű pályakezdőktől elsősorban megbízhatóságot, precizitást, a szaktudás gyakorlati alkalmazását, önállóságot, problémamegoldást, terhelhetőséget és munkabírást követelnek meg, vagyis olyan naprakész kompetenciákkal rendelkező munkavállalókat keresnek, akik kreativitásukkal és problémamegoldó képességükkel húzóerőt jelenthetnek a vállalkozásnál. A kutatás eredményei szerint a hallgatók által szükségesnek vélt és a munkaadói oldal által elvárt kompetenciák közül a problémamegoldási készség, a szaktudás gyakorlati alkalmazása, a kommunikációs képesség, az idegen nyelv ismerete, a szervezési készség, a stressztürő képesség, az elemző készség, az analitikus szemlélet, a rugalmasság, valamint a másik ember motiválásának képessége tekintetében mutatkozik eltérés. Vagyis a hallgatók fontosabb munkáltatói elvárásnak gondolják ezeket a kompetenciákat, mint amennyire azok a munkáltatók számára ténylegesen fontosak (Kárpátiné 2014).

A pályakezdők nincsenek könnyü helyzetben a munkaerőpiacon. Esélyeiket nagyban gyengíti az a tény, hogy jellemzően azoknak az ismereteknek vannak szükében, amelyek elvárásként jelentkeznek a foglalkoztatók részéről. A folyamatos kompetencia- és tudásfejlesztés erőteljes elvárása a munkaerőpiacnak. A fiatalok egyik versenytényezője az lehet, hogy jobban, gyorsabban, rugalmasabban tudnak megújulni. Az egész életen át tartó tanulás (LLL: life long learning) koncepciójában lehetőség nyílik arra, hogy frissítsék, újítsák készségeiket, tudásukat, hiszen egy megszerzett felsőfokú végzettség nem jelent biztos munkát, megélhetést a munkaerőpiacon.

Természetesen felvetődik a kérdés, hogy a diákok az iskolapadból hozott hiányosságaik, így a munkahelyi tapasztalat hiánya vagy a nem aktív nyelvtudás, mennyire tudja befolyásolni a munkáltatók foglalkoztatási döntéseit. Ebben szerepet játszhat az úgynevezett alulértékelési tendencia és az iskolai élmények befolyása, amely során a saját maguk megítélésénél az iskolai érdemjegyekből indulnak ki (Czeglédi-Juhász 2014). Emellett az oktatási idő kitolódásával a fiatalok pályaérettsége is változott. Az oktatás és a gyakorlat összehangoltabb együttmüködésére lenne szükség ahhoz, hogy az aktuális piaci igényeknek megfelelő kompetenciákkal rendelkező munkavállalók jelenjenek meg a munkaerőpiacon.

\section{A kutatás módszertana}

A tanulmány alapját egy 2020-ban végzett nem reprezentatív, feltáró jellegű kérdőíves adatfelvétel adja. A kutatás alapvető célja annak megismerése volt, hogy a munkavállalók saját bevallásuk szerint milyen képességek birtokában vannak, és ezek közül melyek milyen értéket képviselnek szerintük a munkaerőpiacon. Jelen tanulmány a munkavállalókkal készült kérdőives felmérés néhány eredményét mutatja be az alábbi két hipotézis tükrében:

H1: A munkavállalók szerint a munkáltatók ma egy hozzájuk jelentkezőtől egyaránt elvárják a puha és a kemény készségek (a soft és a hard skillek) biztos meglétét.

H2: A puha készségek (a soft skillek) önbevallás alapján mért szintjében eltérések mutathatók ki nem, életkor és iskolai végzettség szerint. 
A felmérés során online kérdőívet kellett a válaszadóknak anonim módon kitölteniük. A kérdőív kiküldése előtt voltak próbakitöltések, amelyek során a kutatásban részt vevők nem kérték a kérdések módosítását. Ezek után hólabda módszerrel: e-mailen, a közösségi felületen került szétküldésre a kérdöív. A közösségi oldalakon található baráti csoportok továbbították egymásnak megválaszolására a kérdéseket. Összességében 500 munkavállaló töltötte ki a kérdőívet. Ugyanakkor az adatfelvétel sajátosságaiból adódóan a minta nem tekinthetö reprezentatívnak.

A kérdőív szerkezetét tekintve zárt és nyitott kérdésekből állt. A 28 kérdésből egyre kellett nyitott kérdésként válaszolniuk a kutatásban részt vevőknek. A kérdések alapvetően metrikus és nominális változókra épültek. A kérdőív struktúráját az 1. táblázat mutatja be.

1. táblázat: A kérdőív szerkezete

\begin{tabular}{lll}
\hline \multicolumn{1}{c}{$\begin{array}{c}\text { A minta } \\
\text { specifikálása }\end{array}$} & \multicolumn{1}{c}{$\begin{array}{c}\text { Soft skill } \\
\text { értelmezése }\end{array}$} & \multicolumn{1}{c}{$\begin{array}{c}\text { Soft és hard skill a } \\
\text { munkaeröpiacon }\end{array}$} \\
\hline $\begin{array}{l}\text { Lakóhely } \\
\text { Életkor }\end{array}$ & $\begin{array}{l}\text { Soft skill kifejezés ismerete } \\
\text { Kitöltök soft skilljének, }\end{array}$ & $\begin{array}{l}\text { Soft és hard skillekkel kapcsolatos } \\
\text { elvárások }\end{array}$ \\
$\begin{array}{l}\text { Legmagasabb iskolai } \\
\text { végzettség }\end{array}$ & $\begin{array}{l}\text { szakmai, nyelvi és számítógépes } \\
\text { Családi állapot }\end{array}$ & $\begin{array}{l}\text { Soft skillek értéke a munkaerő- } \\
\text { piacon }\end{array}$ \\
Munkatapasztalat & Munkáltatói elvárások a soft & Soft skill elsajátításának eszközei \\
skillel kapcsolatban & Soft skill fejlesztésének lehetőségei \\
\hline
\end{tabular}

Forrás: Saját adatfelvétel

Az elemzések során a következő statisztikai módszereket alkalmaztuk: gyakorisági eloszlás, átlag, szórás, faktoranalízis, korrelációs vizsgálatok, ANOVA, független mintás T-próba.

\section{A kutatás eredményei}

A kutatásban 157 férfi $(31,4 \%)$ és 343 nő $(68,6 \%)$ vett részt. Életkoruk alapján a legfiatalabb 18 éves, a legidősebb 61. Az átlagos életkor 28,5 év volt. A 18-30 évesek a minta 67,8\%-át, a 31-45 évesek 26\%-át, a 46-60 évesek 6\%-át, míg a 60 év felettiek 0,2\%-át teszik ki. A legmagasabb iskolai végzettség alapján 49 százalékuk érettségivel, 50,6 százalékuk diplomával, míg 0,4 százalékuk doktori fokozattal rendelkezett. Nem volt olyan válaszadó, aki ne végezte volna el a középiskolát, és nem szerzett volna érettségit. Alapfokú végzettséggel rendelkezők tehát nem voltak a mintában, ami torzíthatja az eredményeket.

A legtöbb kutatásban részt vevőnek (84\%-uknak) már volt munkatapasztalata. Minden tízedik megkérdezett már több mint 20 éve dolgozott, de minden nyolcadik válaszadó, ha nem is 20 , de legalább már 10 éve a munkaerőpiacon volt. Természetesen a meglévő munkatapasztalat erősen összefügg a válaszadó életkorával, ezért elemzéseinkbe az életkort vontuk be, de ebből közvetve következtetni lehet a munkatapasztalat szerinti összefüggésekre is.

A továbbiakban a vizsgált két hipotézis mentén mutatjuk be eredményeinket. 


\section{A puba és kemény készségekkel kapcsolatos munkáltatói elvárások értékelése (H1)}

A kérdőív rákérdezett arra, hogy a válaszoló mennyire ismeri a soft skill fogalmát. A fogalom jelentéstartalmát illetően a megkérdezettek 34,4\%-a teljesen biztos volt, 30,6 százalékuk csak részben, míg 35 százalékuk egyáltalán nem ismerte a fogalmat.

A kutatásban részt vevőknek egy ötfokozatú Likert-skálán kellett értékelniük, hogy mennyire kell a munkáltatók szerint egy fiatal jelentkezőnek a kérdőívben felsorolt puha és kemény skillekkel rendelkeznie. Az egyes az egyáltalán nem kell rendelkeznie, míg az ötös érték a teljes mértékben rendelkeznie kell választ jelentette. A 2. táblázat foglalja össze az adott skillek átlagát és szórását.

2. táblázat: A munkáltatói elvárások a puha és a kemény skillekkel kapcsolatban (átlag, szórás)

\begin{tabular}{lcc}
\hline Skillek (puha skill: S, kemény skill: H) & Átlag & Szórás \\
\hline Rugalmasság (S) & 4,46 & 0,757 \\
Csapatmunkára való készség (S) & 4,45 & 0,690 \\
Kommunikációs készség (S) & 4,40 & 0,742 \\
Problémamegoldó képesség (S) & 4,32 & 0,806 \\
Jó kommunikációs készség (S) & 4,22 & 0,776 \\
Nyelvismeret (H) & 4,21 & 0,777 \\
Informatikai ismeretek (H) & 4,15 & 0,729 \\
Stresszhelyzetek és konfliktusok kezelésének képessége (S) & 4,12 & 0,923 \\
Időmenedzsment készségek (S) & 4,01 & 0,913 \\
Szakmai ismeret (H) & 3,95 & 0,830 \\
Tervezési és szervezési készségek (S) & 3,79 & 0,915 \\
Megjelenés / kinézet (S) & 3,75 & 0,871 \\
Prezentációs készségek (S) & 3,74 & 1,060 \\
Kreativitás (S) & 3,63 & 1,090 \\
Stratégiai gondolkodásmód (S) & 3,59 & 1,051 \\
Etikai és erkölcsi képességek (S) & 3,59 & 1,137 \\
Kritikus gondolkodás (S) & 3,40 & 0,999 \\
Empátia (S) & 3,15 & 1,162 \\
Önismeret (S) & 3,07 & 1,183 \\
Érzelmi intelligencia (S) & 3,04 & 1,148 \\
Vállalkozói készségek (S) & 2,91 & 1,111 \\
Vezetői képességek (S) & 2,83 & 0,972 \\
\hline Forras: Syátan & \\
\hline
\end{tabular}

Forrás: Saját adatfelvétel

A 2. táblázat adataiból jól látható, hogy egyes soft skillek szinte még erősebb elvárásként jelentkeznek, mint a hard skillek. A szakmai ismeret viszonylag szilárd követelményként mutatkozik, a rugalmasságot, a megfelelő kommunikációt és a csapatmunkában 
történő aktív részvételt azonban még erősebb munkáltatói elvárásként tartják számon a megkérdezettek. Érdekes módon a megkérdezettek úgy látták, hogy a vezetői készség, avagy a vállalkozói aktivitás elhanyagolhatóbb elvárás a szervezetek részéről.

Elemzésünkben azt is megvizsgáltuk, hogy az adott követelmények közül melyek azok, amelyek a megkérdezettek szerint szoros kapcsolatban vannak egymással. A korrelációs vizsgálatokból azokat a kapcsolatokat elemeztük, ahol az $r$ érték legalább 0,5 feletti volt. A 3. táblázat foglalja össze az egyes puha skillekkel kapcsolatos munkáltatói elvárások szorosságát.

3. táblázat: A puha skillekkel kapcsolatos munkáltói elvárások közötti kapcsolatok és azok szorossága

\begin{tabular}{llc}
\hline Puha skill 1 & Puha skill 2 & $\boldsymbol{r}^{*}$ \\
\hline Vezetöi képesség & Vállalkozói készség & 0,689 \\
Érzelmi intelligencia & Empátia & 0,681 \\
Önismeret & Empátia & 0,652 \\
Stratégia gondolkodásmód & Tervezési és szervezési készségek & 0,626 \\
Etikai és erkölcsi képesség & Empátia & 0,594 \\
Önismeret & Érzelmi intelligencia & 0,587 \\
Időmenedzsment készségek & Tervezési és szervezési készségek & 0,557 \\
Etikai és erkölcsi képesség & Érzelmi intelligencia & 0,541 \\
Stratégia gondolkodásmód & Prezentációs készségek & 0,508 \\
\hline
\end{tabular}

Megjegyzés: ${ }^{*}$ Pearson-féle korrelációs együtthatók $(r)$ alapján $(p<0,01)$. Forrás: Saját adatfelvétel

Elemzésünkben a 2. táblázatban látható skilleket Varimax-rotálással végzett feltáró faktoranalízis segítségével faktorokba tömörítettük varianciahányad-módszerrel (KMO Barlett-teszt $=0,898, \chi^{2}=3929,639, d f=171$, modell szign. $=0,000$; magyarázott varianciahányad $=63,9 \%$ ). Három változó (szakmai ismeret, kreativitás és prezentációs készség) nem volt alkalmas a faktorképzésre (alacsony volt a faktorsúly), így ezek egyik faktorhoz sem tartoznak. Öt faktor került kialakításra, amelyek a faktorsúlyok alapján a következö elnevezéseket kapták:

1. faktor: A szervezeti operatív müködést biztosító képességek (Cronbach- $\alpha=$ $0,808)$.

2. faktor: A szervezeten belül társas kapcsolatokat támogató képességek (Cronbach- $\alpha$ $=0,853)$.

3. faktor: A szervezet vezetését elősegítő képességek (Cronbach- $\alpha=0,853$ ).

4. faktor: A szervezeten belüli kommunikációs folyamatokat támogató képességek (Cronbach- $\alpha=0,731$ ).

5. faktor: A szervezeten belüli operatív tudást erősítő képességek (Cronbach- $\alpha=$ $0,646)$ kemény skillekkel.

A faktorokhoz tartozó skilleket és a faktorsúlyokat a 4. táblázat mutatja. 
4, táblázat: A faktorelemzés során kapott faktorok és faktorsúlyok

\begin{tabular}{|c|c|c|c|c|c|}
\hline Skillek & 1. faktor & 2. faktor & 3. faktor & 4. faktor & 5, faktor \\
\hline Tervezési és szervezetési készségek & 0,685 & & & & \\
\hline Időmenedzsment készségek & 0,678 & & & & \\
\hline Problémamegoldó készségek & 0,648 & & & & \\
\hline Rugalmaság & 0,575 & & & & \\
\hline Stresszhelyzetek & 0,546 & & & & \\
\hline Stratégiai gondolkodásmód & 0,533 & & & & \\
\hline Empátia & & 0,847 & & & \\
\hline Érzelmi intelligencia & & 0,788 & & & \\
\hline Önismeret & & 0,759 & & & \\
\hline Etikai és erkölcsi képességek & & 0,716 & & & \\
\hline Vezetői képességek & & & 0,818 & & \\
\hline Vállalkozói készségek & & & 0,809 & & \\
\hline Kritikus gondolkodás & & & 0,579 & & \\
\hline Jó kommunikációs készség & & & & 0,683 & \\
\hline Megjelenés/kinézet & & & & 0,670 & \\
\hline Csapatmunkára való készség & & & & 0,601 & \\
\hline Kommunikációs készség & & & & 0,597 & \\
\hline Informatikai ismeretek & & & & & 0,822 \\
\hline Nyelvismeret & & & & & 0,768 \\
\hline
\end{tabular}

Forrás: Saját adatfelvétel

Eredményeink összességben azt mutatják, hogy az első hipotézisünkben megfogalmazott állítás részben igazolódott, hiszen számos puha és kemény készség kapcsán kijelenthető, hogy a munkavállalók szerint magas szintü munkáltatói elvárásként jelentkezik, ugyanakkor több skillre (pl. vállalkozói készség, vezetői képesség) kisebb mértékben tekintenek követelményként.

\section{A puha készségek önbevallás alapján mért szintjében háttérváltozók szerint tapasztalható eltérések (H2)}

A kérdőíves felmérés során a megkérdezetteknek, a maguk szemszögéből is nyilatkozniuk kellett, hogy miként értékelik azon puha skilljeiket, amelyekre a munkáltatói elvárások kapcsán is rákérdeztünk. Az egyes a nagyon gyenge, az ötös a kiváló szintet jelentette. Az 5. táblázat az adott képességekre vonatkozó átlagokat és szórásokat mutatja be.

$\mathrm{A} z$ adatok jól érzékeltetik, hogy az adott skillekben erősnek érzik magukat a megkérdezettek, és azokban a képességekben megfelelőnek látják magukat, amelyek fontosak lehetnek a munkaadók számára. Természetesen felvetődik a kérdés, hogy valóban ilyen összhangban vannak-e az elvárások a munkaerőpiacon felellhető munkavállalói képességekkel. 
HORVÁTH-CSIKós G. - JUHÁSZ T.: A PUHA (SOFT) ÉS A KEMÉNY (HARD) KÉSZSÉGEK

5, táblázat: A munkavállalók puha skilljének önbevallás alapján mért szintje (átlag és szórás)

\begin{tabular}{lcc}
\hline Puha skillek & Átlag & Szórás \\
\hline Rugalmasság & 4,46 & 0,757 \\
Etikai és erkölcsi képességek & 4,27 & 0,830 \\
Érzelmi intelligencia & 4,25 & 0,821 \\
Empátia & 4,22 & 1,049 \\
Problémamegoldó képesség & 4,15 & 0,755 \\
Együttmúködési készség (csapatmunka) & 4,06 & 0,952 \\
Tervezési és szervezési készségek & 4,03 & 0,848 \\
Kreativitás & 3,94 & 0,934 \\
Kritikus gondolkodás & 3,94 & 0,859 \\
Önismeret & 3,89 & 0,887 \\
Stratégiai gondolkodásmód & 3,84 & 0,866 \\
Kreativitás & 3,63 & 1,090 \\
Kommunikációs készség & 3,62 & 0,945 \\
Stresszhelyzetek és konfliktusok kezelésének képessége & 3,43 & 1,020 \\
Vezetői képességek & 3,39 & 0,944 \\
Prezentációs készségek & 3,35 & 1,090 \\
Időmenedzsment készségek & 3,34 & 1,037 \\
Vállalkozói készségek & 3,02 & 1,043 \\
\hline
\end{tabular}

Forrás: Saját adatfelvétel

A $\chi^{2}$-próbákkal végzett elemzésünk alapján a felsorolt skillek tekintetében szignifikáns eltérés $(p<0,05)$ mutatható ki nem, iskolai végzettség és életkor alapján. A $z$ iskolai végzettség esetében két kategóriát hoztunk létre: 1) érettségizett és 2) diplomás (mely tartalmazza a PhD-végzettségüeket is). Az életkor kapcsán pedig négy korcsoportot különböztettük meg: 1) 18-30 évesek, 2) 31-45 évesek, 3) 46-60 évesek, és 4) 60 év felettiek. Az elemzés eredményeit a 6. táblázat foglalja össze.

6, táblázat: A képességek különbözősége nem, iskolai végzettség és életkor alapján

\begin{tabular}{llll}
\hline Skillek & \multicolumn{1}{c}{ Nemek } & Iskolai végzettség & \multicolumn{1}{c}{ Életkor } \\
\hline Csapatmunka & $\begin{array}{l}\text { Nincs szignifikáns } \\
\text { különbség }\end{array}$ & $\begin{array}{l}\text { Nincs szignifikáns } \\
\text { különbség }\end{array}$ & $\begin{array}{l}\text { Nincs szignifikáns } \\
\text { különbség }\end{array}$ \\
\hline Empátia & Nők erősebb & Diplomások erősebb & $\begin{array}{l}\text { Nincs szignifikáns } \\
\text { különbség }\end{array}$ \\
\hline Érzelmi intelligencia & Nők erősebb & $\begin{array}{l}\text { Nincs szignifikáns } \\
\text { különbség }\end{array}$ & $\begin{array}{l}\text { Nincs szignifikáns } \\
\text { különbség }\end{array}$ \\
\hline $\begin{array}{l}\text { Etikai és erkölcsi } \\
\text { képességek }\end{array}$ & $\begin{array}{l}\text { Nincs szignifikáns } \\
\text { különbség }\end{array}$ & Diplomások erősebb & 45 év felett erősebb \\
\hline
\end{tabular}


6. táblázat: (folyt.)

\begin{tabular}{|c|c|c|c|}
\hline Skillek & Nemek & Iskolai végzettség & Életkor \\
\hline $\begin{array}{l}\text { Időmenedzsment } \\
\text { készségek }\end{array}$ & Nők erősebb & Diplomások erősebb & $\begin{array}{l}30 \text { és } 45 \text { év között } \\
\text { erősebb }\end{array}$ \\
\hline $\begin{array}{l}\text { Kommunikációs } \\
\text { készség }\end{array}$ & $\begin{array}{l}\text { Nincs szignifikáns } \\
\text { különbség }\end{array}$ & Diplomások erősebb & 45 év felett erősebb \\
\hline Kreativitás & $\begin{array}{l}\text { Nincs szignifikáns } \\
\text { különbség }\end{array}$ & $\begin{array}{l}\text { Nincs szignifikáns } \\
\text { különbség }\end{array}$ & $\begin{array}{l}\text { Nincs szignifikáns } \\
\text { különbség }\end{array}$ \\
\hline Kritikus gondolkodás & Nők erősebb & Diplomások erősebb & 45 év felett erősebb \\
\hline Önállóság & Nők erősebb & $\begin{array}{l}\text { Nincs szignifikáns } \\
\text { különbség }\end{array}$ & $\begin{array}{l}30 \text { és } 45 \text { év között } \\
\text { erősebb }\end{array}$ \\
\hline Önismeret & $\begin{array}{l}\text { Nincs szignifikáns } \\
\text { különbség }\end{array}$ & $\begin{array}{l}\text { Nincs szignifikáns } \\
\text { különbség }\end{array}$ & 45 év felett erősebb \\
\hline $\begin{array}{l}\text { Prezentációs } \\
\text { készségek }\end{array}$ & $\begin{array}{l}\text { Nincs szignifikáns } \\
\text { különbség }\end{array}$ & $\begin{array}{l}\text { Nincs szignifikáns } \\
\text { különbség }\end{array}$ & $\begin{array}{l}\text { Nincs szignifikáns } \\
\text { különbség }\end{array}$ \\
\hline $\begin{array}{l}\text { Problémamegoldó } \\
\text { képesség }\end{array}$ & $\begin{array}{l}\text { Nincs szignifikáns } \\
\text { különbség }\end{array}$ & $\begin{array}{l}\text { Nincs szignifikáns } \\
\text { különbség }\end{array}$ & $\begin{array}{l}\text { Nincs szignifikáns } \\
\text { különbség }\end{array}$ \\
\hline Rugalmasság & $\begin{array}{l}\text { Nincs szignifikáns } \\
\text { különbség }\end{array}$ & $\begin{array}{l}\text { Nincs szignifikáns } \\
\text { különbség }\end{array}$ & $\begin{array}{l}\text { Nincs szignifikáns } \\
\text { különbség }\end{array}$ \\
\hline $\begin{array}{l}\text { Stratégiai } \\
\text { gondolkodásmód }\end{array}$ & Férfiak erősebb & $\begin{array}{l}\text { Nincs szignifikáns } \\
\text { különbség }\end{array}$ & $\begin{array}{l}\text { Nincs szignifikáns } \\
\text { különbség }\end{array}$ \\
\hline $\begin{array}{l}\text { Stresszhelyzetek } \\
\text { és konfliktusok } \\
\text { kezelésének képessége }\end{array}$ & $\begin{array}{l}\text { Nincs szignifikáns } \\
\text { különbség }\end{array}$ & $\begin{array}{l}\text { Nincs szignifikáns } \\
\text { különbség }\end{array}$ & $\begin{array}{l}\text { Nincs szignifikáns } \\
\text { különbség }\end{array}$ \\
\hline $\begin{array}{l}\text { Tervezési és szervezési } \\
\text { készségek }\end{array}$ & $\begin{array}{l}\text { Nincs szignifikáns } \\
\text { különbség }\end{array}$ & $\begin{array}{l}\text { Nincs szignifikáns } \\
\text { különbség }\end{array}$ & 45 év felett erősebb \\
\hline Vállalkozói készségek & $\begin{array}{l}\text { Nincs szignifikáns } \\
\text { különbség }\end{array}$ & $\begin{array}{l}\text { Nincs szignifikáns } \\
\text { különbség }\end{array}$ & $\begin{array}{l}\text { Nincs szignifikáns } \\
\text { különbség }\end{array}$ \\
\hline Vezetői képességek & Férfiak erősebb & $\begin{array}{l}\text { Nincs szignifikáns } \\
\text { különbség }\end{array}$ & $\begin{array}{l}\text { Nincs szignifikáns } \\
\text { különbség }\end{array}$ \\
\hline
\end{tabular}

Forrás: Saját adatfelvétel

Nemek tekintetében elmondható, hogy a férfiak magasabbra értékelik a stratégiai gondolkodásukat és a vezetői képességeiket, mint a nők, miközben az empátia, az érzelmi intelligencia, az időmenedzsment, a kritikus gondolkodás és az önállóság megítélése a nők körében magasabb szintü. Az iskolai végzettség szerinti vizsgálat azt mutatja, hogy azoknál a készségeknél (empátia, etikai és erkölcsi képességek, időmenedzsment, kommunikáció, kritikus gondolkodás), amelyeknél szignifikáns különbség tapasztalható, egyértelműen a diplomások érzik felkészültebbnek magukat. A kor kapcsán általánosságban kijelenhető, hogy inkább idősebb (kvázi a több munkatapasztalattal rendelkezők) számolnak be erősebb skillekről, mely főként az etikai és erkölcsi képességek, a kommunikációs készség, kritikus gondolkodás, az önismeret, valamint a tervezési és szervezési készségek kapcsán érhető tetten. 
Az eredmények alapján elmondható, hogy a felsorolt skillek többségében nem, életkor és/vagy iskolai végzettség szerint lényeges eltérés mutatható ki az önbevallás alapján mért szintjében.

\section{Konklúzió}

Jelen tanulmányban a jelenlegi munkaerőpiacon a puha (soft) és a kemény (hard) készségeket vizsgáltuk egy munkáltatókkal végzett online kérdőíves felmérés eredményei alapján. Elemzésünkben egyrészt a puha és a kemény készségekkel kapcsolatos munkáltatói elvárások munkavállalók általi megítélését, másrészt ezen készségek önbevallás alapján mért szintjében nem, életkor, iskolai végzettség és településtípus szerinti eltéréseket.

A kutatás eredménye rámutatott arra, hogy a munkavállalók szerint egyes puha készségek (például a rugalmasság, kommunikáció, csapatmunka) erősebb munkáltatói elvárásként jelentkeznek, mint a kemény készségek (például szakmai ismeretek). Az eredményekből alapvetően az rajzolódott ki, hogy a soft és hard skillekkel szembeni munkáltatói elvárások kevésbé függnek össze, és a munkavállalók úgy vélik, hogy a munkáltatók ezeket a képességeket nem rendszerszintü, egymással szorosan kapcsolatban álló skillekként értékelik.

Elemzéseink eredményei arra is rámutattak, hogy a diplomások szignifikánsan erösebb kritériumnak érzik a vezetés működését biztosító képességeket, a kommunikációt támogató skilleket, és a szervezeti tudásvagyont támogató képességeket, mint az érettségivel rendelkezők. Nemek tekintetében elmondható, hogy a férfiak magasabbra értékelik a stratégiai gondolkodásukat és a vezetői képességeiket, mint a nők. A kor kapcsán pedig az látható, hogy jellemzően a több munkatapasztalattal rendelkezők számolnak be erősebb skillekről, mely főként az etikai és erkölcsi képességek, a kommunikációs készség, kritikus gondolkodás, az önismeret, valamint a tervezési és szervezési készségek kapcsán érhető tetten. Az eredményeket értékelve elmondható, hogy a nem, az életkor és az isko-

lai végzettség a legtöbb esetben összefügg a vizsgált készségek önbevallás alapján mért szintjével.

A vizsgálat folytatásaként a kutatók a munkáltatói oldalt is megkérdezik majd, hogy az ő elvárásaik és a tapasztalataik mennyire csengenek egybe a dolgozói elvárásokkal és a munkavállalók magukról alkotott képével.

\section{Köszönetnyilvánítás}

A tanulmány az Innovációs és Technológiai Minisztérium ÚNKP-20-4 kódszámú Új Nemzeti Kiválóság Programjának a Nemzeti Kutatási, Fejlesztési és Innovációs Alapból finanszírozott szakmai támogatásával készült.

\section{IRODALOM}

Czzeglédi Cs. \& Juhász T. (2014) A pályakezdők munkaerő-piaci megfelelése a pályakezdők szemszögéből. Taylor: gazdálkodás-és szervezéstudományi folyóirat, Vol. 6. Nos 3-4. pp. 91-97. 
European Commission (2011) Draft 2012 Joint Report of the Council and the Commission on the Implementation of the Strategic Framework for European Cooperation in Education and Training (ET2020). https://eurlex.europa.eu/LexUriServ/LexUriServ. do?uri=COM:2011:0902:FIN:EN:PDF

HALÁsz G. (2013) Élethosszig tartó tanulás: 21. századi paradigma vagy múló divat? In: Kraiciné Szokoly M., PÁpai A. \& Perjés I. (eds) Európai léptékkel. Az élethosszig tartó tanulás. Budapest, Eötvös Kiadó. pp. 13-26.

Kárpátiné D. J. (2014) A kompetencia hatalom? Mit ér a gazdasági felsőfokú képzés, ba nem ad diplomát? http://realphd.mtak.hu/624/1/Karpatine_Daroczi_Judit_dissertation.pdf [Letöltve: 2020. 10. 10.]

Laker, D. R. \& Powell, J. L. (2011) The Differences between Hard and Soft Skills and Their Relative Impact on Training Transfer. Human Resource Development Quarterly, Vol. 22. No. 1. pp. 111-122. (online) http://dx.doi.org/10.1002/hrdq.20063

LinkedIn (2019) Global Talent Trends 2019. https://business.linkedin.com/talent-solutions/ resources/talent-strategy/global-talent-trends-2019 [Letöltve: 2020. 11.23.]

National Soft Skills Association (2015) The Soft Skills Disconnect. https://www. nationalsoftskills,org/the-soft-skills-disconnect/ [Letöltve: 2021. 11. 21.]

Schulz, B. (2008) The Importance of Soft Skills: Education Beyond Academic Knowledge. NAWA Journal of Language and Communication, DOI: 10.1016/0006-3207(93)90452-7

Seetha, S. (2013) Necessity of Soft Skills Training for Students and Professionals. International Association of Scientific Innovation and Research, Vol. 4. No. 2. pp. 171-174.

Tribble, L. S. (2020) The Importance of Soft Skills in the Workplace as Perceived by Community College Instructors and Industries. (Doctoral dissertation, Mississippi State University.)

A cikk a Creative Commons Attribution 4.0 International License (https://creativecommons.org/licenses/ by/4.0/) feltételei szerint publikált Open Access közlemény, melynek szellemében a cikk bármilyen médiumban szabadon felhasználható, megosztható és újraközölhető, feltéve, hogy az eredeti szerző és a közlés helye, illetve a CC License linkje és az esetlegesen végrehajtott módosítások feltüntetésre kerülnek. (SID_1) 